\title{
REVIEW
}

\section{The Management of Open Fractures}

\author{
Robert H. Quinn, MD, FAAOS; Darryl J. Macias, MD, FACEP \\ From the Departments of Orthopaedic Surgery (Dr Quinn) and Emergency Medicine and International/Wilderness Medicine (Dr Macias), \\ University of New Mexico, Albuquerque, NM.
}

\begin{abstract}
This is a review of Medline and PubMed articles on open fractures published in the English literature between 1945 and April 2005. The emphasis of most published articles has been placed on definitive treatment of these injuries at sophisticated referral hospitals. The prehospital emphasis has been on rapid evacuation and referral to ensure that definitive treatment can be initiated as quickly as possible. Little has been discussed about the management of these injuries in remote settings where evacuation may consume considerably more time. Contemporary recommendations for management of these injuries are reviewed.
\end{abstract}

Key words: fracture, open, compound, wilderness, injury

\section{Introduction}

Approximately 6 million fractures occur annually in the United States. ${ }^{1}$ Almost 250000 or $4 \%$ of these fractures are open. ${ }^{2}$ Open fractures remain one of the most potentially devastating of orthopaedic injuries, with associated complications such as amputation, osteomyelitis, and nonunion. In view of the complexity of these injuries and their management, they have received significant attention; however, most of this attention has been directed at definitive treatment after arrival to an emergency department. The prehospital emphasis has been on rapid evacuation and referral to ensure that definitive treatment can be initiated as rapidly as possible. Little has been discussed about the management of these injuries in remote settings where evacuation may consume considerably more time.

\section{Methods}

A search of the US National Library of Medicine Medline and PubMed database for articles on open fractures was conducted. Terms used in the search included open fractures, compound fractures, and wilderness injuries. Articles in the English language or with English abstracts published between 1945 and April 2005 were reviewed. The bibliographies of pertinent articles were

\footnotetext{
Corresponding author: Robert H. Quinn, MD, Department of Orthopaedic Surgery, MSC10 5600, University of New Mexico, Albuquerque, NM 87131 (e-mail: rquinn@salud.unm.edu).
}

also reviewed for manuscripts that may not have been indexed in Medline or PubMed. These articles and abstracts were reviewed in light of the first author's (R.H.Q.) experience treating open fractures in the wilderness setting and at a level I trauma center.

\section{Discussion}

An open fracture involves a break in the overlying skin that leads to direct communication between the fractured bone and the environment in which the injury occurred. This communication results in contamination and the potential for infection.

Open fractures are most widely classified according to the system of Gustillo et $\mathrm{al}^{3}$ and Gustillo and Anderson $^{4}$ (Table 1). This classification scheme provides guidelines for prognosis and helps predict outcome based on the degree of soft tissue injury. Although originally described by Gustillo et $\mathrm{al}^{3}$ as a means to grade open tibia fractures, the system is currently used to describe all open fractures. Examples are shown in Figures 1 and 2 .

The initial treatment of a patient with an open fracture consists of a primary survey as outlined by the Advanced Trauma Life Support protocol. ${ }^{5}$ After the patient has been assessed and stabilized, the injured limb should be realigned and a neurovascular assessment performed. ${ }^{5-8}$ There is no evidence to support the concept of splinting a deformed extremity as it lies in the field, and this practice can lead to an unnecessary level of 
Table 1. Classification of open fractures

\begin{tabular}{ll}
\hline Type & Description \\
\hline 1 & Clean wound less than $1 \mathrm{~cm}$ long \\
2 & Wound greater than $1 \mathrm{~cm}$ long without extensive soft tissue damage, flaps, or avulsions \\
$3 \mathrm{~A}$ & Extensive soft tissue laceration or flaps but adequate soft tissue coverage possible without flaps; \\
& any wound associated with high-energy trauma \\
$3 \mathrm{~B}$ & Extensive soft tissue loss with periosteal stripping and bone exposure; requires local or free tis- \\
& sue transfer to cover exposed bone \\
$3 \mathrm{C}$ & Open fracture associated with arterial injury requiring repair
\end{tabular}
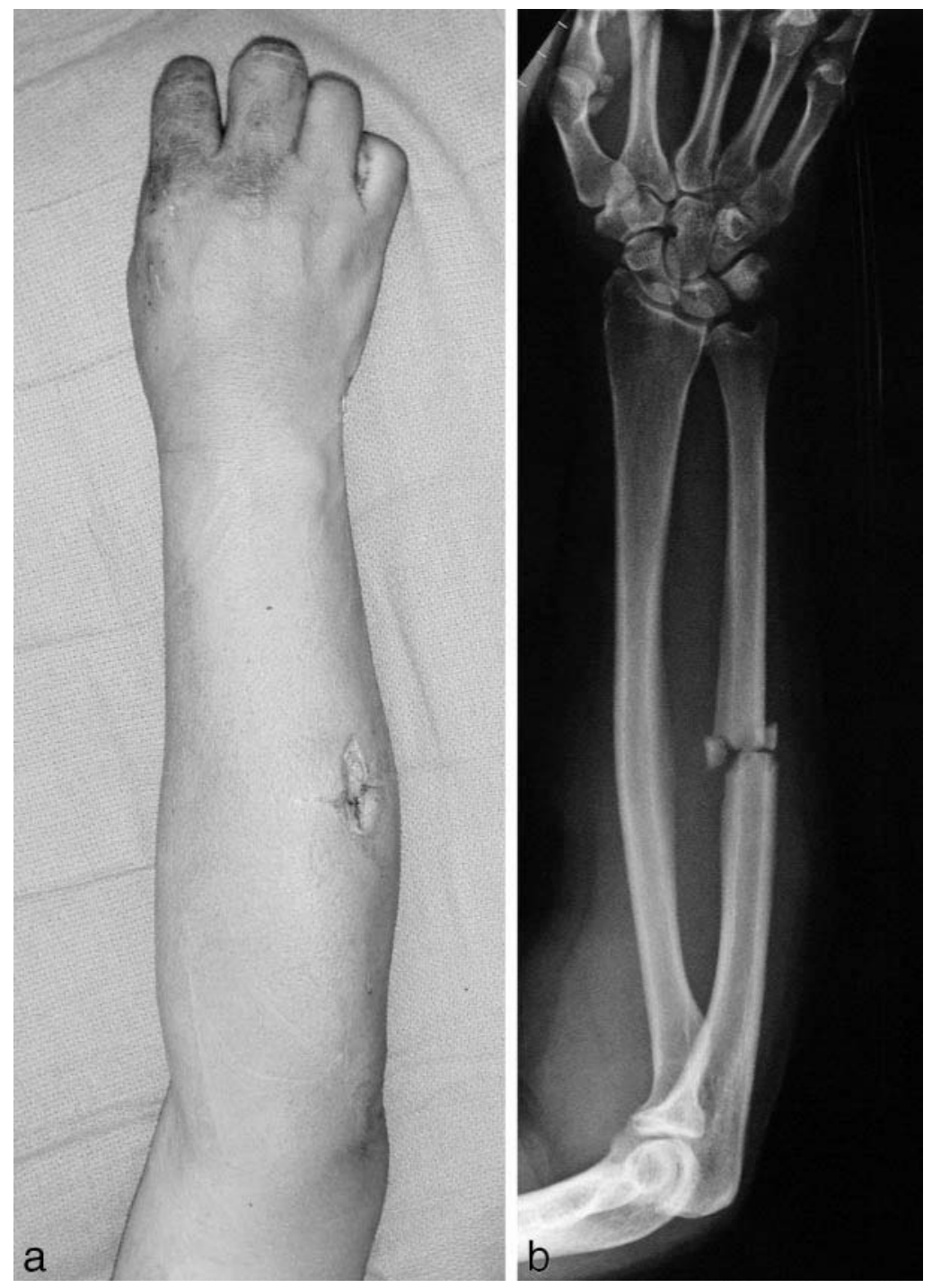

Figure 1. Clinical photograph (a) and radiograph (b) of a type 1 open fracture of the ulnar shaft. 


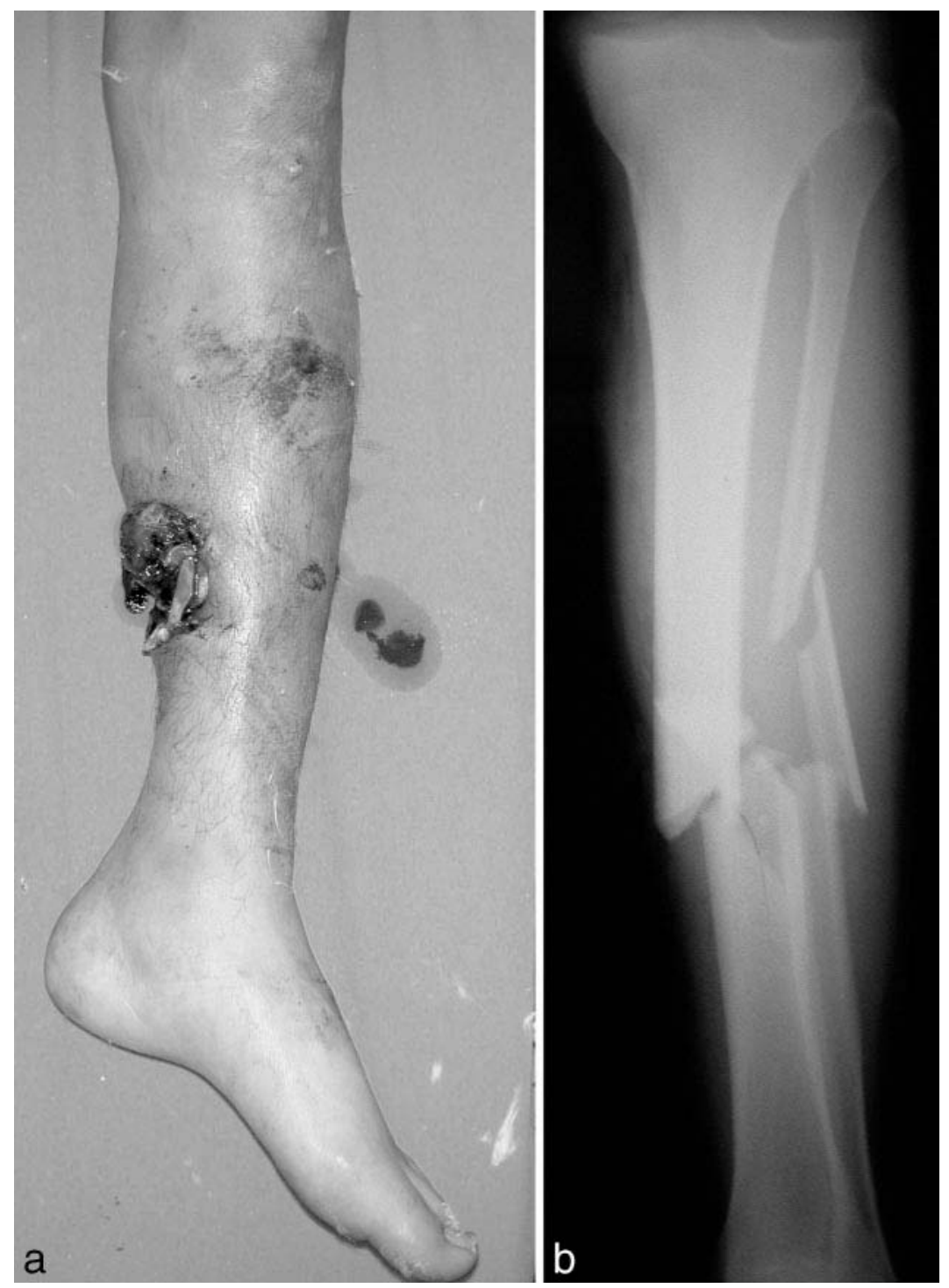

Figure 2. Clinical photograph (a) and radiograph (b) of a type 3B open fracture of the tibial shaft.

pain, increased neurovascular compromise, as well as increased tension on soft tissue that is already compromised. If gross contamination is present, or if a delay in the time to debridement is anticipated, the wound should be irrigated with $1 \mathrm{~L}$ of sterile normal saline and then covered with a sterile dressing, and the fracture should be splinted. The dressing should not be removed until the patient is in the operating room for definitive treatment. A substantial increase in infection rate occurs with multiple inspections of the wound before debridement. ${ }^{9}$

Second to ischemia from vascular injury, infection represents the most potentially severe complication of open fractures. Staphylococcus aureus and coagulasenegative staphylococci are the most common organisms causing infection in open fractures, ${ }^{10,11}$ though infec- tions caused by gram-negative organisms have increased recently. ${ }^{12,13}$ Injuries occurring in water may lead to infection with Aeromonas or Pleisomonas. ${ }^{14}$ Puncture wounds of the foot are often associated with Pseudomonas aeroginosa infection. ${ }^{14}$ Contamination with soil can lead to clostridial infection. ${ }^{15}$

Patzakis $^{16}$ reported a contamination rate of $64 \%$ in open fractures. Despite the high rate of contamination, infection is unlikely to occur with fewer than $10^{5}$ bacteria per gram of tissue. ${ }^{17}$ Robson and associates ${ }^{18}$ showed in an animal model that a bacterial colony count greater than $10^{5}$ colony-forming units occurs in a traumatic wound within 5 hours of injury. Because 5 hours is required for an inoculation to result in more than $10^{5}$ bacteria per gram of tissue, this defines the "golden pe- 
Table 2. Systemic therapy for open fractures in adults*

\begin{tabular}{|c|c|c|c|}
\hline \multirow[b]{2}{*}{ Agent } & \multicolumn{3}{|c|}{ Open fracture type } \\
\hline & 1 & 2 & 3 \\
\hline Cephazolin $1 \mathrm{~g}$ IV/IM every $8 \mathrm{~h}+t$ & $\mathrm{X}$ & $\mathrm{X}$ & $\mathrm{X}$ \\
\hline $\begin{array}{l}\text { Aminoglycoside } 5 \mathrm{mg} \cdot \mathrm{kg}^{-1} \cdot \mathrm{d}^{-1} \mathrm{IM} / \mathrm{IV} \text { divided } \\
\text { every } 12 \mathrm{~h} \S\end{array}$ & & & $\mathrm{X}$ \\
\hline Penicillin $2000000 \mathrm{U}$ IV/IM every $4 \mathrm{~h} \hbar$ & $\mathrm{X} \|$ & $\mathrm{X} \|$ & $\mathrm{X}$ \\
\hline Tetanus prophylaxis & $\mathrm{X}$ & $\mathrm{X}$ & $\mathrm{X}$ \\
\hline
\end{tabular}

*IV indicates intravenously; IM, intramuscularly; PO, by mouth; QID, 4 times per day; and BID, 2 times per day.

$\dagger$ Alternatives to cephazolin: ceftriaxone $1 \mathrm{~g}$ IM every 24 hours; cephalexin $500 \mathrm{mg}$ PO QID + ciprofloxacin $750 \mathrm{mg}$ PO BID, erythromycin $500 \mathrm{mg}$ PO every 6 hours, and amoxicillin $500 \mathrm{mg}$ PO every 8 hours.

\$For penicillin/cephalosporin allergic: clindamycin $900 \mathrm{mg}$ IV every 8 hours or $450 \mathrm{mg}$ PO every 6 hours.

$\S$ May need to be altered with impaired renal function.

|With contamination in a farm environment.

riod," after which the risk of infection increases dramatically as more time elapses between injury and definitive treatment in an operating room.

Because all open fracture wounds are potentially contaminated, systemic antibiotics are administered to treat the contamination, not as prophylaxis. For this reason, antibiotics should be administered as soon as possible after the injury.

A prospective, controlled, randomized study compared 3 groups of patients with open fractures. ${ }^{11}$ The first group received cephalothin, the second group received penicillin and streptomycin, whereas the third group received no antibiotics. The infection rates were $2.3 \%, 9.7 \%$, and $13.9 \%$, respectively. A similar study reported an infection rate of $4.8 \%$ in open fractures treated with antibiotics compared with $28 \%$ in patients treated with placebo. ${ }^{19}$ Antibiotics with broad-spectrum gram-positive coverage such as a first-generation cephalosporin should therefore be used for all open fractures (Table 2). This coverage appears adequate for types 1 and 2 fractures. For type 3 fractures, the addition of an aminoglycoside is recommended to provide added gramnegative coverage. A single daily dose of gentamicin (6 $\left.\mathrm{mg} \cdot \mathrm{kg}^{-1}\right)$ is as effective as divided doses and is not associated with an increase in adverse effects. ${ }^{20}$ All type 3 open fractures and any open wounds occurring around farms have a higher risk of clostridial contamination, and these patients should also be given anaerobic coverage in the form of penicillin or metronidazole. Antibiotics are generally administered for 3 days in types 1 and 2 fractures and for 5 days in type 3 fractures, though this duration is somewhat empiric. All patients not immunized within 5 years of their injuries should receive a tetanus toxoid injection. Patients who have never been immunized should receive tetanus immunoglobulin in addition to a tetanus toxoid injection.
Although antibiotic administration is an important adjunct in the treatment of open fractures, irrigation and debridement are by far the most important measures in preventing infection. Antibiotics alone cannot be relied upon to prevent infection in an inadequately debrided wound. ${ }^{21-23}$

Hair around an open wound should be removed to facilitate wound care and healing. This should be accomplished by clipping, not shaving, because shaving increases the wound infection rate by traumatizing the skin and hair follicles, resulting in a dermatitis. ${ }^{24-29}$

Adequate surgical debridement is the single most important factor in minimizing the risk of infection with open fractures. ${ }^{30,31}$ Devitalized soft tissues increase the risk of infection by acting as a culture medium for bacteria, by directly inhibiting leukocytic phagocytosis, and by providing an anaerobic environment that further inhibits leukocyte function. ${ }^{24}$ Optimally, debridement should be performed in an operating room. The wound should be generously extended to expose the entire wound area to healthy tissue. Early after injury, it is often difficult to determine the zone of devitalization of soft tissues. Sharp excision of 1 to $2 \mathrm{~mm}$ of the exposed skin edges should be performed. By 24 hours after injury, devitalized skin is clearly demarcated. Devitalized subcutaneous fat and fascia should be sharply debrided. Necrotic muscle is the major medium for bacterial growth, and its presence increases the risk of anaerobic infection. ${ }^{32,33}$ Retained necrotic muscle can also have potentially serious systemic effects, including myoglobinuria and renal failure. Underestimating the extent of muscle damage at the time of initial debridement is common. Muscle that is not contractile, is discolored, or does not bleed when cut should be excised. Tendons are not a major source of infection and should be preserved where possible. The associated paratenon (the thin are- 
olar layer surrounding a tendon) is necessary for tendon survival and, if exposed, should be kept moist until the wound can be closed or covered with a soft tissue flap. ${ }^{32}$ Minor vessels can be ligated. Major vessels and nerves should be preserved. In type 3C fractures, circulation should be restored to the limb as quickly as possible. Complete loss of blood supply to a limb for more than 8 hours nearly always results in amputation. ${ }^{6}$ Bone fragments that lack soft tissue attachment, and therefore blood supply, should be excised. Avascular fragments of bone become necrotic and may serve as sequestra. A $50 \%$ increase in infection rate has been reported in a study of high-grade open tibia fractures with retention of large segments of necrotic bone. ${ }^{34}$ Major segments of bone containing articular cartilage should be retained regardless of soft tissue attachments or wound type, as meaningful reconstruction of the joint may be dependent upon these segments.

Irrigation of contaminated wounds has been shown to be an effective means of decreasing bacterial load and removing foreign debris. ${ }^{35-45}$ Anglen $^{46}$ has provided an excellent review of wound irrigation in musculoskeletal injury. High-pressure pulsatile lavage is thought to further enhance microorganism removal. ${ }^{41,42,45}$ By providing alternating pulse compression and decompression phases, soft tissue recoil is allowed, which may enhance dislodgement of particulate matter. Some studies, however, have shown no benefit of pulsatile lavage over continuous-flow irrigation. ${ }^{44,47}$ High-pressure irrigation does carry a risk of potential complications. One in vivo study demonstrated visible bone damage at the fracture site and delayed healing associated with high-pressure pulse lavage. ${ }^{40}$ Another study reported that high-pressure irrigation of in vitro fractured tibiae resulted in macroscopic bony damage and pushed surface bacteria into the intramedullary canal. ${ }^{48}$ Low-pressure irrigation causes less bone damage and can be as effective as highpressure lavage in removing bacteria when performed soon after contamination. Bhandari et $\mathrm{al}^{49}$ showed less microscopic and macroscopic bone damage with lowpressure than with high-pressure irrigation and no difference in ability to remove bacteria if either procedure is performed within 3 hours of contamination. However, low-pressure irrigation was less effective in removing bacteria if performed more than 3 hours after injury. The pressure exerted by fluid delivered through a 19-gauge needle by a $35-\mathrm{mL}$ syringe is 8 psi. ${ }^{50}$ Pressures of 8 psi or higher have been designated high pressure. Madden et $\mathrm{al}^{47}$ irrigated contaminated wounds in rabbits with 300 $\mathrm{mL}$ of saline at pressures of $0.5,10$, and 25 psi after delays of 5 minutes, 2 hours, and 4 hours. Increasing pressure increased bacterial removal at all times, but with the 2- and 4-hour delays only irrigation at 25 psi significantly decreased the rate of infection.

The optimal volume of irrigation that should be used is not clear. One animal study has demonstrated that increasing volume of saline irrigation from $0.1 \mathrm{~L}$ to $1.0 \mathrm{~L}$ increased the effectiveness of bacterial removal, but further increases up to $10 \mathrm{~L}$ provided no additional benefit. ${ }^{51}$ No human studies have been reported.

Various studies have evaluated the use of additives to irrigation as well as the effectiveness of topical solutions. Mixed results have been reported. The 3 general categories of additives include antiseptics, antibiotics, and surfactants.

Antiseptics act by damaging the cell wall or cell membrane of the pathogen, but as a result of this mechanism of action they are also toxic to host cells. Examples include povidone-iodine solution, hydrogen peroxide, hexachlorophene, sodium hypochlorite, and others. There are few data to support a lower infection rate with the use of these agents in musculoskeletal wounds; however, there is substantial evidence that further wound damage may occur with their use. ${ }^{46,52}$

The addition of antibiotics to irrigation solutions has also demonstrated mixed results. There is little convincing evidence that the topical use of antibiotics adds any benefit over systemic administration alone, and reports of anaphylaxis and other major complications have been reported. $46,53-55$

Surfactants act by inhibiting bacterial adhesion. Although some surfactants are also antiseptic agents, most act simply by enhancing removal of bacteria through irrigation. Studies have demonstrated enhanced bacteria removal with surfactants compared with saline. ${ }^{51,56-61}$ There are reports attributing toxicity to host tissues with the use of surfactants, but these are largely in vitro studies that use high surfactant concentration and allow prolonged exposure. ${ }^{62-64}$ Although no analyses of the use of soap solutions in the treatment of open fractures in humans have been performed, their use appears to enhance the effectiveness of bacterial removal through wound irrigation and carries a low risk for tissue toxicity if promptly removed through adequate irrigation. ${ }^{46}$

Once adequate debridement and irrigation have been performed, the bone is stabilized. Stabilization generally consists of external fixation, intramedullary nailing, or plate and screw fixation. Small wounds are occasionally closed primarily, though most wounds are left open initially to allow repeated debridement. Optimal wound closure should occur within 3 to 7 days. ${ }^{7}$

\section{Application to wilderness medicine}

The preceding describes the "state-of-the-art" for open fracture management, but it assumes that the injury oc- 
curred in urban surroundings and that evacuation to a definitive treatment center can be performed in a timely fashion. In the wilderness, evacuation can be prolonged well beyond the so-called golden period. Little has been written about the management of open fractures when they occur in remote areas where definitive management may be many hours, or even days, removed.

Open fractures that occur in a setting where it can be anticipated that the patient will be treated within 5 to 8 hours should optimally be treated with administration of antibiotics. Antibiotic administration is most conveniently given intravenously, though intramuscular administration results in equivalent serum levels. If parenteral antibiotics are not available, the oral forms listed in Table 2 should provide adequate bone penetration. Irrigation of the wound should be performed with a $35-\mathrm{mL}$ syringe with a 19-gauge needle or a $12-\mathrm{mL}$ syringe with a 22 gauge needle. If these are not available, low-pressure irrigation delivered by any available means appears to be as effective if administered promptly. Tap water has been shown to be as safe and effective as sterile saline. ${ }^{65,66}$ Some reports have shown a lower infection rate with tap water. ${ }^{65}$ Presumably, filtered or treated water obtained in the wilderness should be as effective as tap water, though this has not been formally studied. At least 1 to $3 \mathrm{~L}$ should be used, more if available. Application of a soap solution (such as castile soap, commonly used in the wilderness) before irrigation is probably beneficial, particularly in highly contaminated wounds, provided it can be removed through adequate irrigation. The optimal concentration of the soap solution is unknown. After irrigation, the wound should be covered with a sterile dressing and the fracture should be reduced and splinted.

When open fractures occur in a remote setting where the patient is not likely to receive definitive treatment within 5 to 8 hours of the injury, adding hematoma evacuation and debridement to the above recommendations appears reasonable if these can be performed by an experienced care provider with adequate equipment. Debridement should be performed only if it can be done safely with minimal risk of hemorrhage or further injury to vital neurovascular structures. The risk of infection, as well as its consequences, and therefore the decision to perform debridement and the degree to which it is performed can be stratified in open fractures. Open fractures of the lower extremity, particularly the tibia, have the highest risk of infection and the most severe morbidity with established infection. Open fractures in the upper extremity, particularly the hand, are less likely to become infected, and their established infections are generally easier to treat. Antibiotic treatment should be continued until the patient reaches a hospital setting, if possible. The initial dressing should not be changed if applied after appropriate irrigation has been performed.

Caloric requirements in the injured patient are high, and nutrition should be maintained with prolonged extrication. Hypothermia and frostbite are additional concerns with wilderness injuries; warming should be a priority and extremities must be protected from frostbite.

\section{Conclusion}

Two hundred fifty thousand open fractures occur annually in the United States, most as a result of vehicular trauma. The number of these fractures that occur in wilderness settings is unknown. Nevertheless, a significant percentage of wilderness injuries likely produce open fractures. Appropriate early management of these injuries can decrease the risk of serious sequellae, including limb loss. Little has been published about the early management of these injuries in the field, with emphasis in the literature placed primarily on evacuation and timely definitive treatment. Extrapolating the recommendations for definitive management of open fractures from the hospital setting to the field, particularly in those cases where definitive treatment may be significantly delayed, may result in a substantial decrease in devastating complications, most notably infection.

\section{References}

1. Praemer A, Furner S, Rice DP. Musculoskeletal Conditions in the United States. Park Ridge, IL: American Academy of Orthopaedic Surgeons; 1992.

2. Court-Brown CM, McQueen MM, Quaba AA. Management of Open Fractures. London, UK: Martin Dunitz; 1996.

3. Gustilo RB, Mendoza RM, Williams DN. Problems in the management of type III (severe) open fractures: a new classification of type III open fractures. J Trauma. 1984; 24:742-746.

4. Gustilo RB, Anderson JT. Prevention of infection in the treatment of one thousand and twenty-five open fractures of long bones: retrospective and prospective analyses. $J$ Bone Joint Surg Am. 1976;58:453-458.

5. Committee on Trauma. Advanced Trauma Life Support (ATLS). Chicago, IL: American College of Surgeons; 2000.

6. Olson SA, Finkmeier CG, Moehring HD. Open fractures. In: Bucholz RW, Heckman JD, eds. Rockwood and Green's Fractures in Adults. 5th ed. Philadelphia, PA: Lippincott Williams \& Wilkins: 2001:285-317.

7. Olson SA, Schemitsch EH. Open fractures of the tibial shaft: an update. Instr Course Lect. 2003;52:623-631.

8. Behrens FF, Sirkin MS. Fractures with soft tissue injuries. In: Browner BD, Jupiter JB, Levine AM, Trafton PG, eds. 
Skeletal Trauma. 3rd ed. Philadelphia, PA: WB Saunders; 2003:293-319.

9. Tscherne H. The management of open fractures. In: Tscherne H, Gorzen L (eds). Fractures With Soft Tissue Injuries. New York, NY: Springer Verlag; 1984.

10. Gustilo RB, Simpson L, Nixon R, Ruiz A, Indeck W. Analysis of 511 open fractures. Clin Orthop. 1969;66: 148-154.

11. Patzakis MJ, Harvey JP Jr, Ivler D. The role of antibiotics in the management of open fractures. J Bone Joint Surg Am. 1974;56:532-541.

12. Patzakis MJ, Wilkins J, Moore TM. Use of antibiotics in open tibial fractures. Clin Orthop. 1983;178:31-35.

13. Patzakis MJ, Wilkins J, Moorte TM. Considerations in reducing the infection rate in open tibial fractures. Clin Orthop. 1983;178:36-41.

14. Patzakis MJ, Wilkins J, Brien WW, Carter VS. Wound site as a predictor of complications following deep nail punctures to the foot. West J Med. 1989;150:545-547.

15. Robinson D, On E, Hadas N, Halperin N, Hofman S, Boldur I. Microbiologic flora contaminating open fractures: its significance in the choice of primary antibiotic agents and the likelihood of deep wound infection. J Orthop Trauma. 1989;2:283-286.

16. Patzakis MJ. Management of open fracture wounds. Instr Course Lect. 1987;36:367-369.

17. Cooney WP III, Fitzgerald RH Jr, Dobyns JH, Washington JA II. Quantitative wound cultures in upper extremity trauma. J Trauma. 1982;22:112-117.

18. Robson MC, Duke WF, Krizek TJ. Rapid bacterial screening in the treatment of civilian wounds. J Surg Res. 1973; 14:426-430.

19. Braun R, Enzler MA, Rittmann WW. A double-blind clinical trial of prophylactic cloxacillin in open fractures. $J$ Orthop Trauma. 1987;1:12-17.

20. Sorger JI, Kirk PG, Ruhnke CJ, et al. Once daily, high dose versus divided, low dose gentamicin for open fractures. Clin Orthop. 1999;366:197-204.

21. Heitmann C, Patzakis MJ, Tetsworth KD, Levin LS. Musculoskeletal sepsis: principles of treatment. Instr Course Lect. 2003;52:733-743.

22. Worlock P, Slack R, Harvey L, Mawhinney R. The prevention of infection in open fractures: an experimental study of the effect of antibiotic therapy. J Bone Joint Surg Am. 1988;70:1341-1347.

23. Worlock P, Slack R, Harvey L, Mawhinney R. The prevention of infection in open fractures: an experimental study of the effect of fracture stability. Injury. 1994;25: 31-38.

24. Edlich RF, Rodeheaver GT, Morgan RF, Berman DE, Thacker JG. Principles of emergency wound management. Ann Emerg Med. 1988;17:1284-1302.

25. Dineen P, Dursin L. Epidemics of postoperative wound infections associated with hair carriers. Lancet. 1973;2: 1157-1159.

26. Seropian R, Reynolds BM. Wound infections after pre- operative depilation versus razor preparation. Am J Surg. 1971;121:251-254.

27. Cruse PJE, Foord R. A five-year prospective study of 23,649 surgical wounds. Arch Surg. 1973;107:206-210.

28. Alexander JW, Fischer JE, Boyajian M, et al. The influence of hair removal methods on wound infections. Arch Surg. 1983;118:347-351.

29. Edlich RF, Rodeheaver GT, Thacker JG, et al. Technical factors in wound management. In: Hunt TK, Dunphy JE, eds. Fundamentals of Wound Management. New York, NY: Appleton-Century-Crofts; 1979.

30. Gustillo RB. Management of Open Fractures and Their Complications. Philadelphia, PA: WB Saunders; 1982.

31. Tetsworth K, Cierny G III. Osteomyelitis debridement techniques. Clin Orthop. 1999;360:87-96.

32. Olson SA. Open fractures of the tibial shaft. J Bone Joint Surg Am. 1996;78:1428-1437.

33. Tscherne H, Gotzen L, eds. Fractures With Soft Tissue Injury. Berlin, Germany: Springer Verlag; 1984.

34. Edwards CC, Simmons SC, Browner BD, Weigel MC. Severe open tibial fractures: results treating 202 injuries with external fixation. Clin Orthop. 1988;230:98-115.

35. Esterhai JL Jr, Queenan J. Management of soft tissue wounds associated with type III open fractures. Orthop Clin North Am. 1991;22:427-432.

36. Gustilo RB, Merkow RL, Templeman D. The management of open fractures. J Bone Joint Surg Am. 1990;72:299304.

37. Patzakis MJ. Management of open fracture wounds. Instr Course Lect. 1987;36:367-369.

38. Bhhaskar SN, Cutright D, Runsuck EE, Gross A. Pulsating water jet devices in debridement of combat wounds, Mil Med. 1971;136:264-266.

39. Brown LL, Shelton HT, Bornside GH, Cohn I Jr. Evaluation of wound irrigation by pulsatile jet and conventional methods. Ann Surg. 1978;187:170-173.

40. Dirschl DR, Duff GP, Dahners LE, Edin M, Rahn BA, Miclau T. High pressure pulsatile lavage irrigation of intraarticular fracture: effects on fracture healing. J Orthop Trauma. 1998;12:460-463.

41. Gross A, Bhaskar SN, Cutright DE, Beasley JD III, Perez B. The effect of pulsating water jet lavage on experimental contaminated wounds. J Oral Surg. 1971;29:187-190.

42. Gross A, Cutright DE, Bhaskar SN. Effectiveness of pulsating water jet lavage in the treatment of contaminated crush wounds. Am J Surg. 1972;124:373-377.

43. Hamer ML, Robson MC, Krized TJ, Southwick WO. Quantitative bacterial analysis of comparative wound irrigations. Ann Surg. 1975;181:819-822.

44. Rhodeheaver GT, Pettry D, Thacker JG, Edgerton MT, Edlich RF. Wound cleansing by high pressure irrigation. Surg Gynecol Obstet. 1975;141:357-362.

45. Sobel JW, Goldberg VM. Pulsatile irrigation in orthopedics. Orthopedics. 1985;8:1019-1022.

46. Anglen JO. Wound irrigation in musculoskeletal injury. $J$ Am Acad Orthop Surg. 2001;9:219-226.

47. Madden J, Edlich RF, Schauerhamer R, Prusak M, Borner 
J, Wangensteen OH. Application of principles of fluid dynamics to surgical wound irrigation. Curr Top Surg Res. 1971;3:85-93.

48. Bhandari M, Adili A, Lachowski RJ. High pressure pulsatile lavage of contaminated human tibiae: an in vitro study. J Orthop Trauma. 1998;12:479-484.

49. Bhandari M, Schemitsch EH, Adili A, Lachowski R, Shaughnessy SG. High and low pressure pulsatile lavage of contaminated tibial fractures: an in vitro study of bacterial adherence and bone damage. J Orthop Trauma. 1999;13:526-533.

50. Stevenson TR, Thacker JG, Rodeheaver GT, et al. Cleansing the traumatic wound by high pressure syringe irrigation. JACEP. 1976;5:17-21.

51. Gainor BJ, Hockman DE, Anglen JO, Christensen G, Simpson WA. Benzalkonium chloride: a potential disinfecting irrigation solution. J Orthop Trauma. 1997;11: 121-125.

52. Kaysinger KK, Nicholson NC, Ramp WK, Kellam JF. Toxic effects of wound irrigation solutions on cultured tibiae and osteoblasts. J Orthop Trauma. 1995;9:303-311.

53. Golightly LK, Branigan T. Surgical antibiotic irrigations. Hosp Pharm. 1989;24:116-119.

54. Nachamie BA, Siffert RS, Bryer MS. A study of neomycin instillation into orthopedic surgical wounds. JAMA. 1968; 204:687-689.

55. Sprung J, Schedewie HK, Kampine JP. Intraoperative anaphylactic shock after bacitracin irrigation. Anesth Analg. 1990;71:430-433.

56. Moussa FW, Gainor BJ, Anglen JO, Christensen G, Simpson WA. Disinfecting agents for removing adherent bac- teria from orthopaedic hardware. Clin Orthop. 1996;329: 255-262.

57. Tarbox BB, Conroy BP, Malicky ES, et al. Benzalkonium chloride: a potential disinfecting irrigation solution for orthopaedic wounds. Clin Orthop. 1998;346:255-261.

58. Anglen J, Apostoles PS, Christensen G, Gainor B, Lane J. Removal of surface bacteria by irrigation. J Orthop Res. 1996;14:251-254.

59. Singleton AO Jr, Davis D, Julian J. The prevention of wound infection following contamination with colon organisms. Surg Gynecol Obstet. 1959;108:389-392.

60. Falconer B, Liljedahl SO, Olovson T. On the effect of treatment of traumatic wounds with soap solution: an experimental study. Acta Chir Scand. 1952;103:222-235.

61. Bhandari M, Adili A, Schemitsch EH. The efficacy of lowpressure lavage with different irrigating solutions to remove adherent bacteria from bone. J Bone Joint Surg Am. 2001;83:412-419.

62. Effendy I, Maibach HI. Detergent and skin irritation. Clin Dermatol. 1996;14:15-21.

63. Rydberg B, Zederfeldt B. Influence of cationic detergents on tensile strength of healing skin wounds in the rat. Acta Chir Scand. 1968;134:317-320.

64. Peterson LW. Prophylaxis of wound infection: studies with particular reference to soaps and irrigation. Arch Surg. 1945;50:177-183.

65. Angeras MH, Brandberg A, Falk A, Seeman T. Comparison between sterile saline and tap water for the cleaning of acute traumatic soft tissue wounds. Eur J Surg. 1992; 158:347-350.

66. Moscati R, Mayrose J, Fincher L, Jehle D. Comparison of normal saline with tap water for wound irrigation. Am J Emerg Med. 1998;16:379-381. 